\title{
Artists of discovery
}

\author{
The past century or so has seen a growing divide between the sciences and the arts. But a recent bout \\ of exhibitions, biographies and documentaries illustrates how arbitrary the distinction between plant \\ scientist and botanical artist really is.
}

Currently in the grounds of Wimpole Hall in Cambridgeshire, UK, there are a number of somewhat anachronistic metal structures scattered through the parkland. At first glance, they look not unlike small gibbets, but closer inspection reveals that they each comprise an easel with a mirror suspended above it. This contemporary art installation celebrates the 300th anniversary of the birth of Lancelot 'Capability' Brown, the great English landscape architect and garden designer.

During the eighteenth century, Capability Brown was responsible for shaping almost 200 gardens and parks of country houses in the UK, including Blenheim Palace in Oxfordshire, Harewood House in Yorkshire and Warwick Castle. The artworks at Wimpole Hall (created by the design practice NEON) emphasize that Brown approached landscape design with a painter's eye - but he was also an engineer who experimented with the latest technological advances of his time.

Such synergy of art and plant science at all scales can be seen throughout the centuries following the Renaissance. And, if it can be said that landscape architects operate at the grand scale, at the other end of the spectrum must be the botanical illustrator.

James Sowerby, a contemporary of Brown, is the subject of a recent book by Paul Henderson subtitled The Enlightenment's Natural Historian. Sowerby was active during the late eighteenth and early nineteenth centuries, a period between the times of Carl Linnaeus and Charles Darwin when describing and cataloguing the diversity of flora and fauna was booming. Sowerby was prolific, both illustrating the scientific works of others and performing his own research that resulted in his naming many species of plant and fungi. However, he worked from specimens and sketches collected and returned to England by others - such as Ferdinand Bauer, who was born three years after Sowerby in 1760 and outlived him by four.

Bauer was Austrian but moved to England in 1787, having accompanied the Oxford University botanist John Sibthorp on a tour of Greece that resulted in Flora Graeca, a book to which Sowerby also contributed illustrations. Bauer accompanied the botanist Robert Brown on the HMS Investigator under the command of Captain Matthew Flinders on a voyage to Australia. There he spent two years drawing over 1,700 plants and 300 animals. Most of these sketches are in the collection held by the Naturhistorisches Museum in Vienna, but his watercolour illustrations are in the library of the Natural History Museum in London. Last year, a book by Paul Martyn Cooper celebrated the work both of Ferdinand and his brother Franz, who, while his brother was globetrotting, had spent 50 years as the resident artist at the Royal Botanic Gardens, Kew (Images of Nature: The Bauer Brothers).

These travels of Ferdinand Bauer, though, are as nothing compared with the intrepid exploits of Maria Sibylla Merian, an exhibition of whose paintings, entitled Maria Merian's Butterflies, is currently running at The Queen's Gallery in Buckingham Palace, London.

Merian was born in Frankfurt in 1647, and early on developed a prodigious talent for painting and illustration, publishing her first book of botanical illustrations in 1675 . She was also fascinated with insects - in particular their metamorphoses, resulting in a further volume in 1679. Her personal life was eventful and, by the 1690 s, she was divorced and living in Amsterdam with her youngest daughter. She decided to travel to Surinam in South America to study and document local insects, and in 1699 she sold almost all of her possessions to fund the trip, including 255 of her paintings. She intended to spend five years in Surinam but contracted malaria in 1701 and had to return.

Merian's art focuses mainly on insects and the plasticity of their forms, but she was also a formidable botanical illustrator. The butterflies and moths that were her passion are placed on no-less-carefully realized examples of the plants on which they lived. These flowers were no mere background; the stages of their lives are as carefully observed and documented as the insects. Although Merian died in poverty in 1717 , the book that resulted from her Surinam adventure,
Metamorphosis Insectorum Surinamensium, was influential long afterwards and was used by Carl Linnaeus when creating his classification system.

Another intrepid artist and botanist, Marianne North, is the subject of the new documentary The Remarkable Miss North, which is being aired on the Smithsonian TV channel in association with CBS Productions. She was born in Norfolk in 1830 and, aged 26, was inspired to see the tropics after a visit to the Palm House at Kew and seeing, in particular, the Pride of Burma, Amherstia nobilis. Despite having no botanical training, she proceeded to collect, archive and annotate every species of grass around her. She was taught watercolours by Valentine Bartholomew, the Flower Painter in Ordinary to Queen Victoria, but preferred oil painting, which she called a "vice like dram drinking". After her father died in 1869, she began travelling alone, at one point visiting twelve countries in six years. She was an unconventional botanical illustrator, working in oils directly on paper and painting both the plants and their surroundings.

North was a conscientious plant collector and has a species of pitcher plant, Nepenthes northiana, named after her. However, her most concrete legacy is the gallery of her art at the Royal Botanic Gardens, Kew. Not only did she donate the paintings, she also paid for the building and hung her art somewhat curiously en masse, tier upon tier like a giant's stamp collection. When her request that refreshments should be available in the gallery was refused, she had coffee and tea plants painted onto its doors instead.

It is hardly surprising that artists have been drawn to the plant kingdom for inspiration, given its rich abundance of forms and colours. But an artist's desire to see beyond the superficial and present a true representation of their subject is no different to a scientist's drive to understand the mechanics of the natural world. In former times, the likes of North, Bauer, Sowerby and Merian saw no contradiction in using art to advance scientific knowledge. That so few equivalents exist today impoverishes both science and art alike. 